\title{
Building Futures, Saving Pasts - Sustainable Development and Heritage Preservation the SPI Way Larry COBEN
}

\begin{abstract}
Archaeological sites are disappearing at a rapidly accelerating rate. While destruction by ISIS and looting get all the press, the primary causes of cultural heritage loss are economic: commercial and residential development and encroachment, mining, energy, agriculture and looting to name a few. If the source of the problem is economic, so must the solutions be. In this talk, I discuss what types of economic solutions are most likely to succeed and which are destined to fail. I will describe why smaller scale projects incorporating women's empowerment and sustainable community development actually work, and why large scale projects divorced from business reality rarely do. Successful programs allow communities to build their futures and save their pasts.
\end{abstract}

Keywords: Sustainable Development, Community, Women's Empowerment, Cultural Heritage, Preservation.

With an investment of $\$ 40,000$, twenty community members in the impoverished community of San Jose de Moro, Peru, site of an important Moche and Lambayeque cemetery have sustainable jobs as artisans and providing tourist services. At the site of Chotuna, Peru, twelve women use native cotton to weave beautiful textiles based on the iconography of the site, helping to feed their families and achieving some financial independence. At the monumental pilgrimage site of Pachacamac, 24 women, trained in business skills and design, have sold iconography-based souvenirs to over 100,000 tourists who visit the site for $\$ 10,000$ last year and for more than $\$ 15,000$ this year. One of these women expressed well the views of her fellow community members when she noted that "This project is a dream come true. We had always hoped for an economic opportunity, but never thought we would have the chance".

These and other small scale non-destructive heritage and economic development projects, undertaken by the Sustainable Preservation Initiative, have not only alleviated poverty, empowered local entrepreneurs and communities and provided opportunities to women who are often excluded from the economic sphere, but changed dramatically community attitudes toward their past together with looting and encroachment upon their sites.

While the horror of explosions leveling buildings in Palmyra and other Middle Eastern sites dominates the news, destruction of cultural heritage by Daesh and other terrorists represents only a small portion of the daily loss of our cul- 


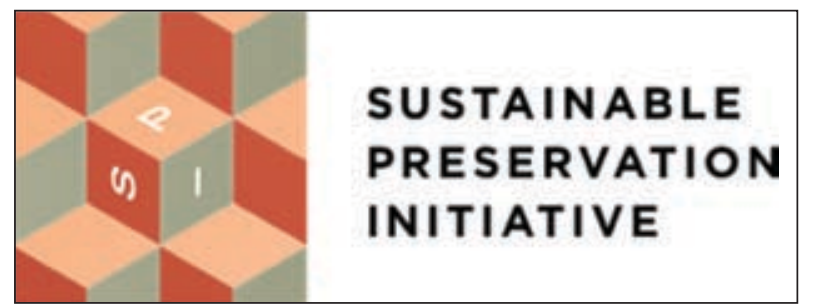

Figure 1.

SPI Logo

tural patrimony. The rest is vanishing from economic causes such as residential construction, farming, industrial agriculture, mining, energy extraction and transmission, looting, grazing and commercial development.

Many of humanity's most important heritage sites co-exist with some of the world's poorest people. Their combined futures are uncertain and often in danger. They need the economic activity described above to survive. How can we justify asking them to not destroy their heritage unless we offer them an economic alternative?

Fortunately, there's a better way-a win-win approach that preserves these sites while helping the surrounding communities. Rather than lament the loss or discuss the reconstruction of ancient buildings in unstable regions, we must collaborate with each site's community, giving the people the tools to profit from their heritage, economically and sustainably. If we make an archaeological wonder not just a thing of beauty and history but also something that provides growth and jobs, it is a win-win proposition for heritage and for households. We build futures while saving the past.

Sustainable development, with its focus on developing businesses and jobs whose success is tied to the ongoing preservation of a site, creates a powerful and long-term incentive and source of funding for the preservation we all want. This paradigm provides all of the benefits normally associated with economic development: employment, health, food and shelter. It is a competitive alternative to other, more destructive economic uses. People gain dignity from being able to work and "consume" their history without destroying it.

Where we have employed this paradigm, looting and encroachment on the sites have essentially ceased.

Drones are utilized to monitor and measure these successes. The local communities have taken a leading role in preserving their past in order to build their futures.

Again, all of the businesses we support are locally owned and managed, and thus the benefits accrue to the community.

Most importantly, these programs empower local people and give them the resources and capacity to control their destiny and to contribute to the 


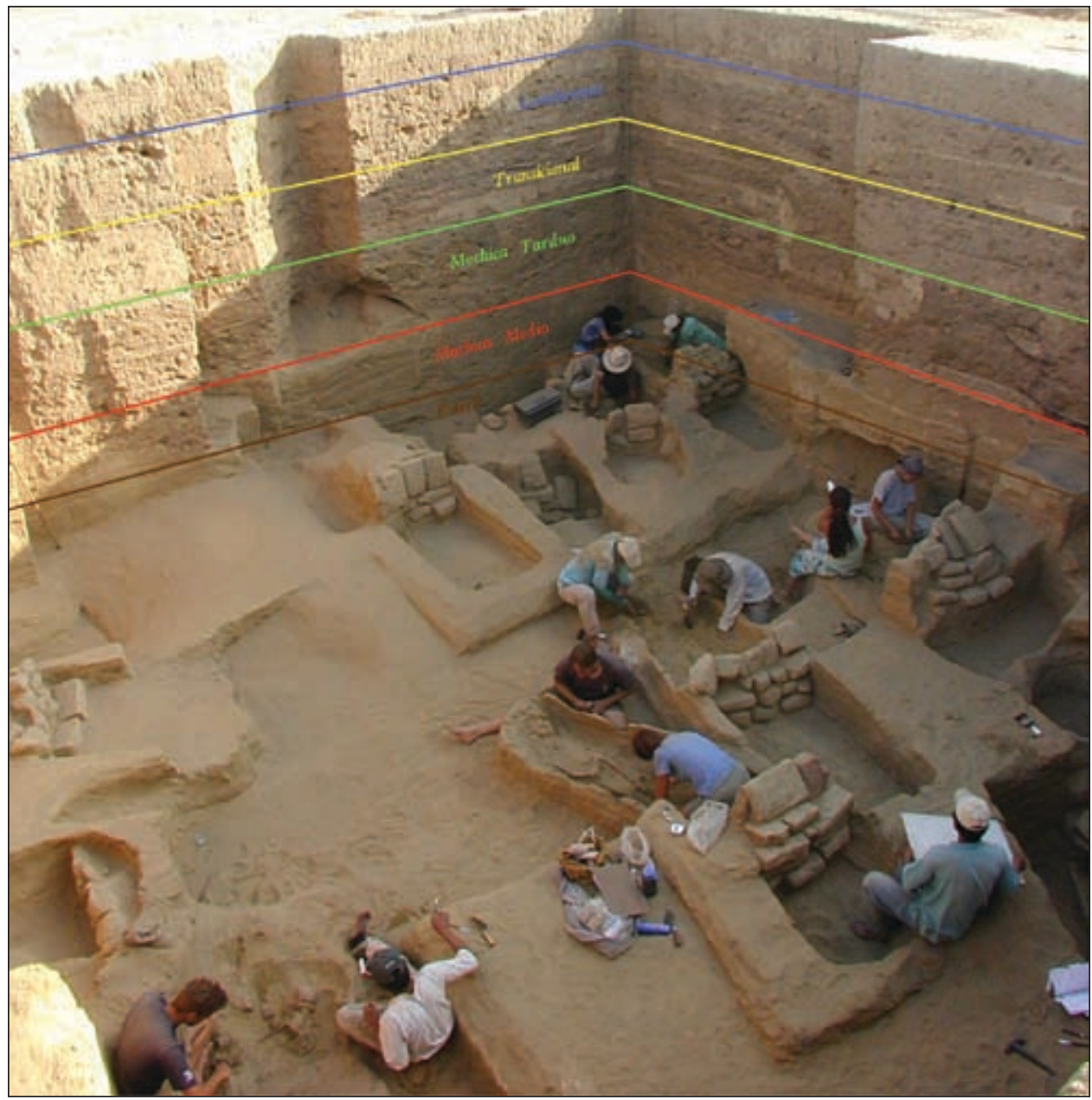

Figure 2. Excavations at San Jose de Moro, Peru (photo, L.J. Castillo)
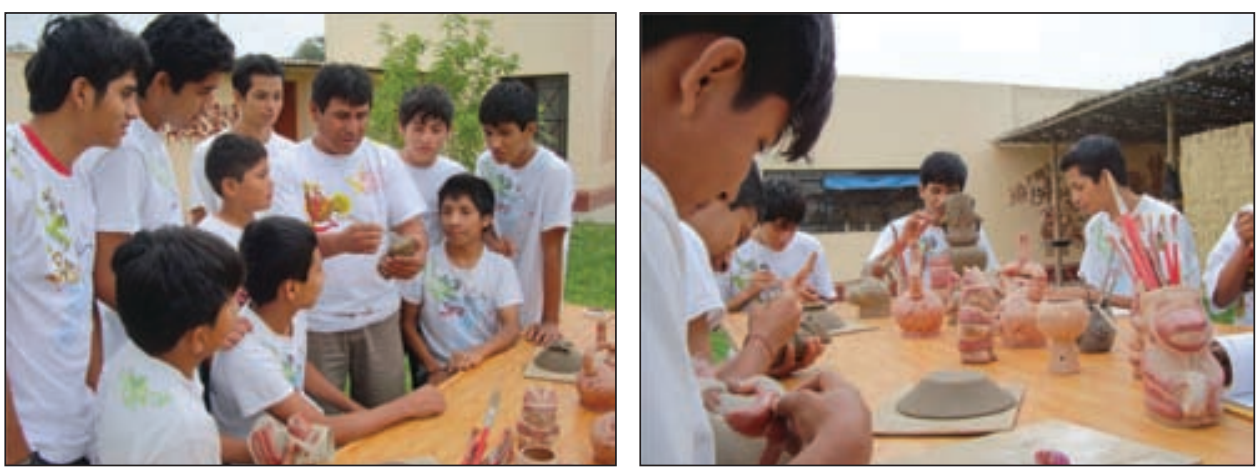

Figure 3-4. Master craftsman Julio Ibarrola teaches young residents how to make their own Moche replicas 


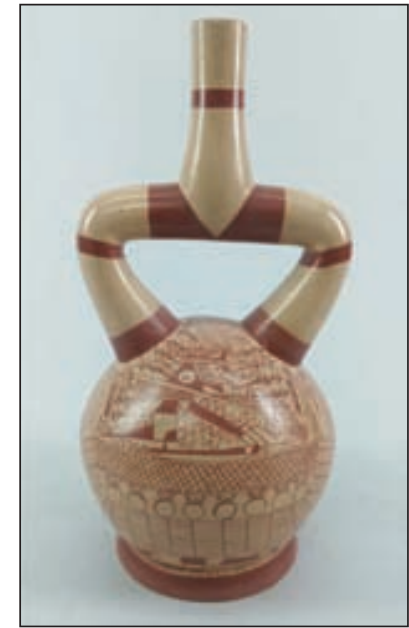

Figure 5. Moche spout bottle replica

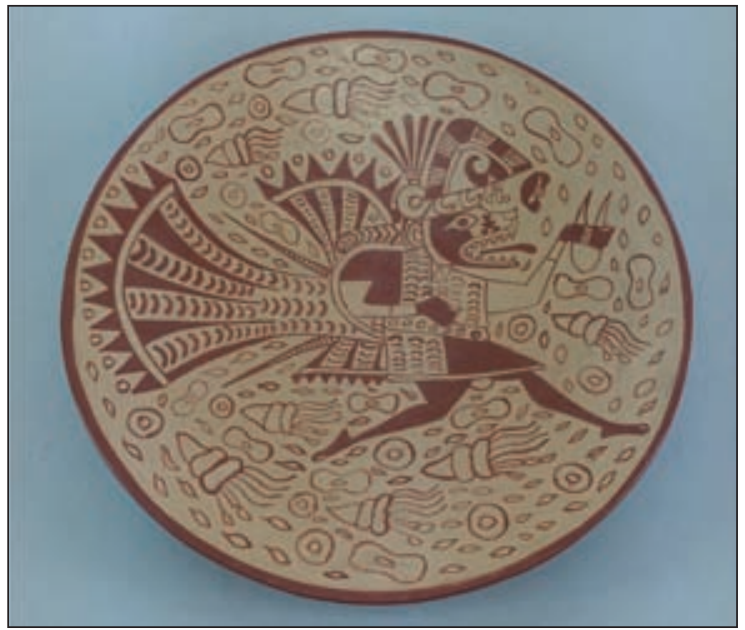

Figure 6. Plate with Moche designs

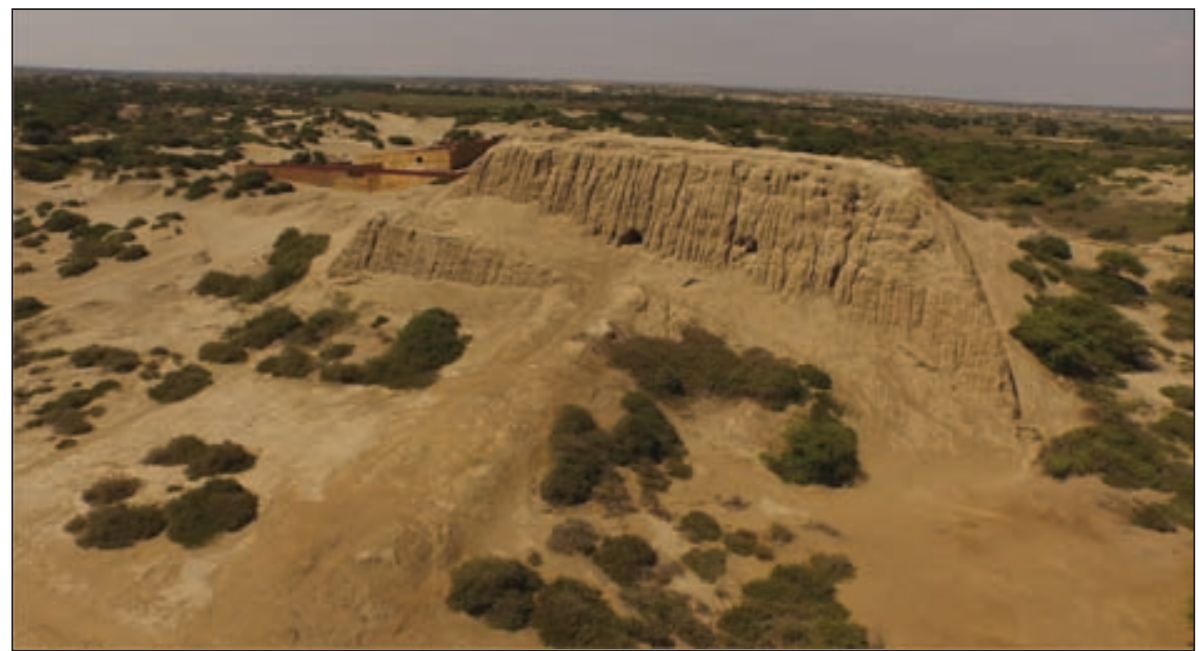

Figure 7. Site of Chotuna-Chornancap

preservation of our collective past. People engaged to such an extent rarely become violent extremists who wish to destroy what remains of the ancient world or attack our modern one. The investment is usually less than $\$ 50,000$ per site - a small amount to pay for saving sites and building engaged and productive futures.

How do we implement these projects successfully? I set forth a few of the critical elements below:

Begin by asking local people what they want and need. See if the proposed project is actually of interest to them and if it matches their hopes and dreams. If it does not, STOP-your project has little or no chance of success. 


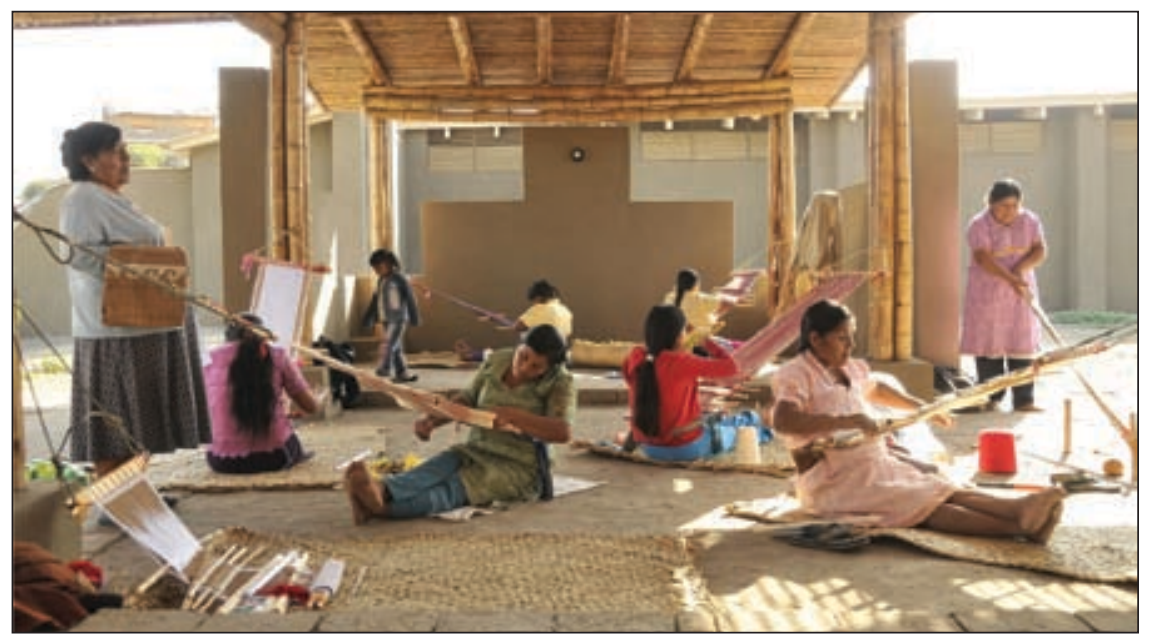

Figure 8. Weavers/Members of Ceterni cooperative, Chotuna-Chornancap, Peru
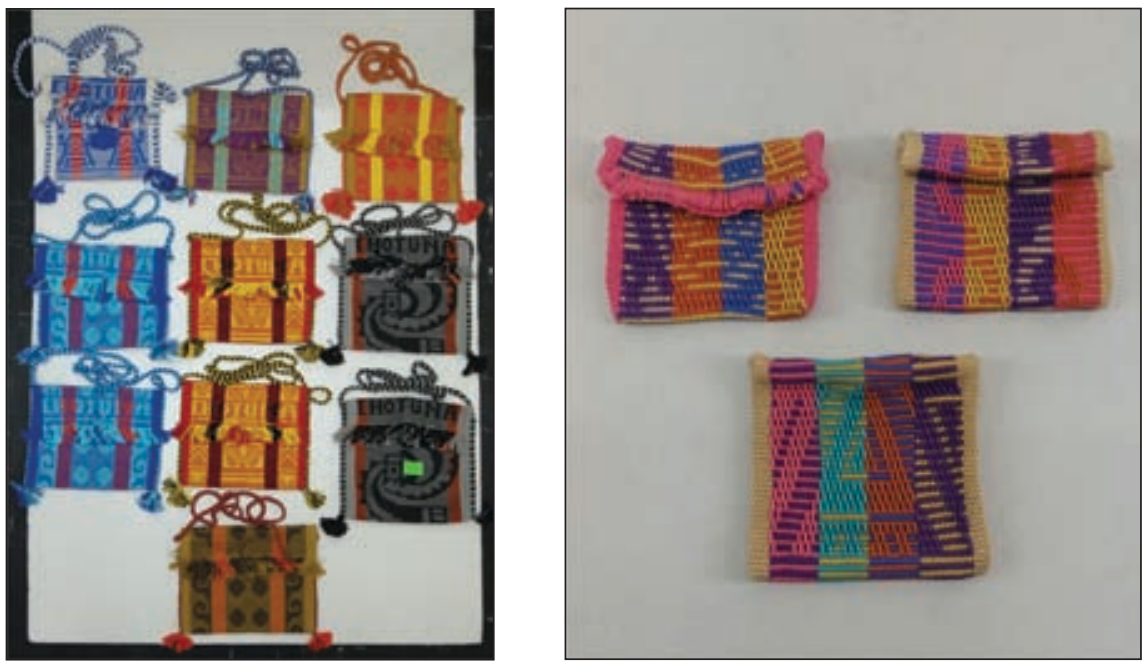

Figure 9-10. Products of the Ceterni cooperative

1. We provide knowledge and resources that create economic opportunities that these communities can seize. Do it the right way, and they will seize them successfully, thrive and build themselves a better future....not just economically, but in health, education and other important areas. THIS IS WHAT WE DO IN SPI!

2. We have designed and implemented a broad capacity training program that empowers communities with the skills necessary to flourish in the modern economy. A mini business school! We do not teach local residents how to make pretty crafts...we teach them how to make products and manage businesses 


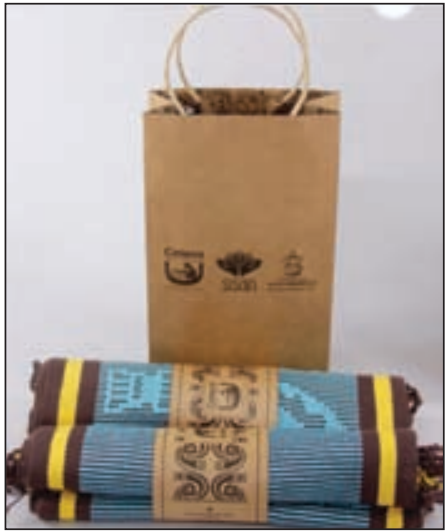

Figure 11. Products of the Ceterni cooperative

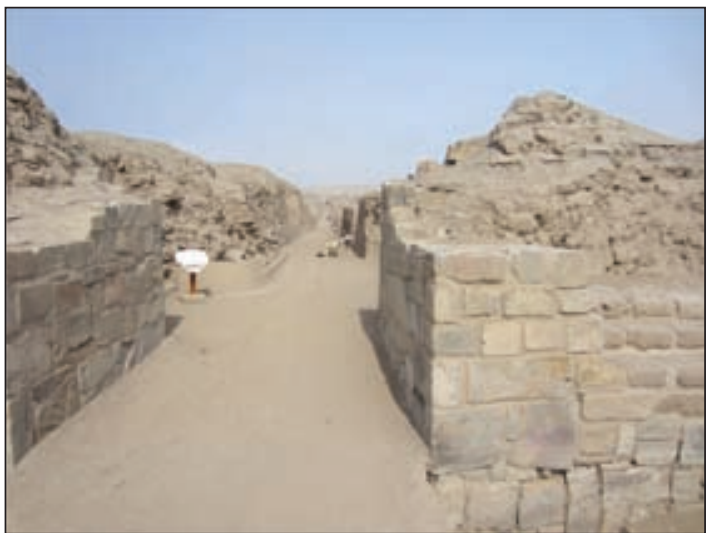

Figure 12. Site of Pachacamac, Peru and the proximity of the surrounding community

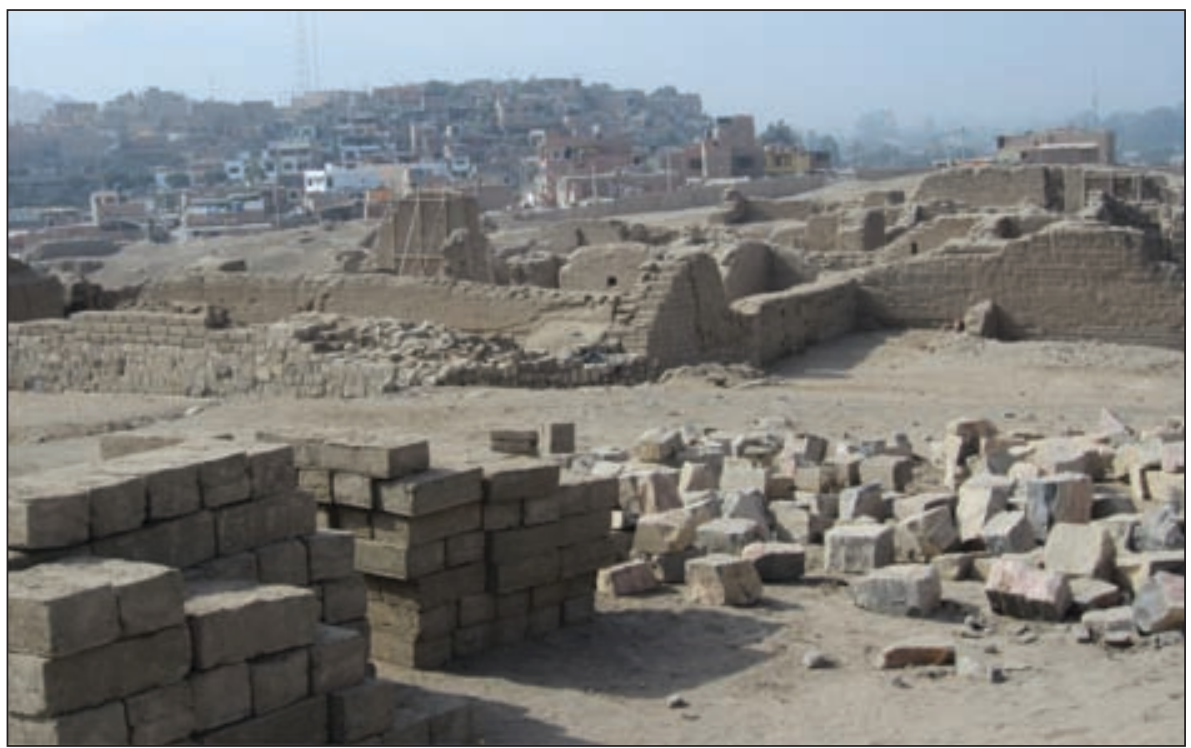

Figure 13. Members of the SISAN cooperative, Pachacamac

that sustain themselves for long periods of time, rather than creating a dependency on outside organizations and funders.

3. We do not build giant visitors' centers or site museums that are not sustainable and whose maintenance budgets are greater than the local community's income. Minimal infrastructure - yes, massive and unsustainable - never. The world is filled with abandoned, run down and underutilized structures that are easy to build and do not relate in any way to community needs or desires.

4. We also invest the necessary seed capital for these new businesses to take root and grow. As the old adage tells us - teach a man to fish, and you 


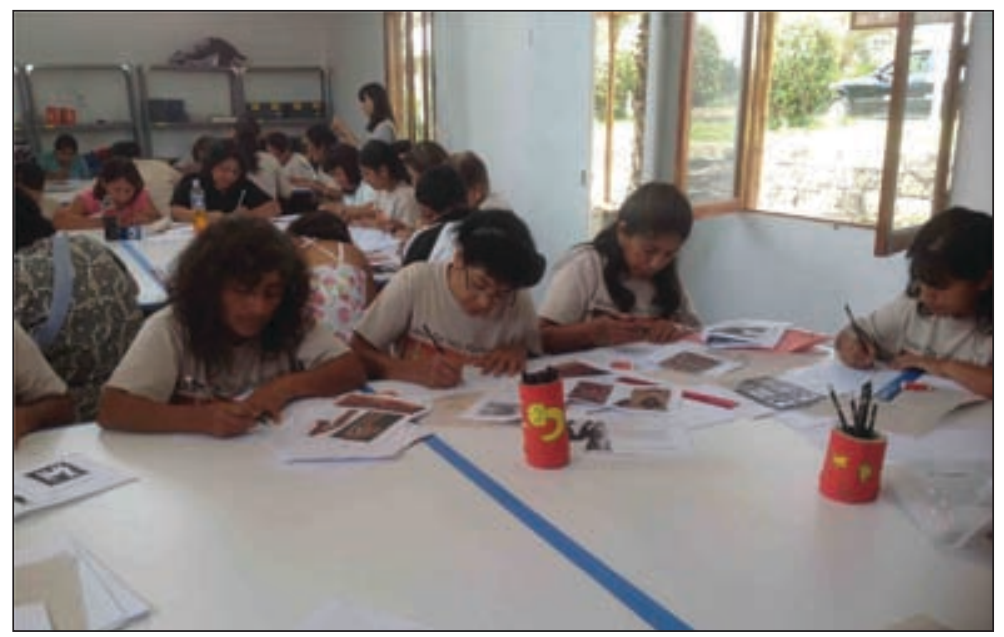

Figure 14. Members of the SISAN cooperative, Pachacamac

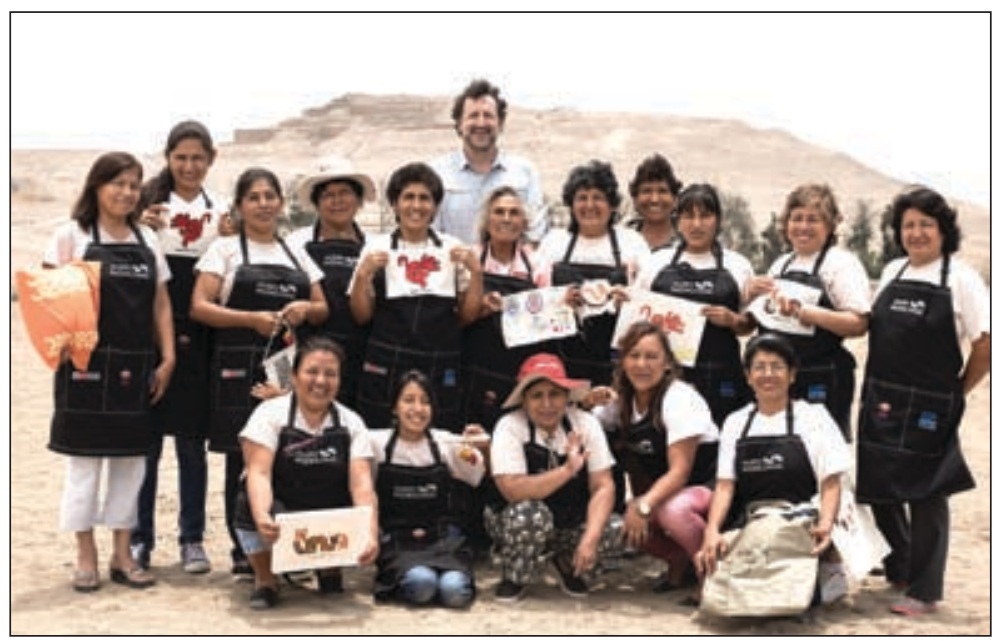

Figure 15. Members of the SISAN cooperative with the author

have fed him for a lifetime. It is necessary to make sure they have access to a rod and a boat! All the capacity training in the world will not help without the necessary capital!

5. An important aspect of our program is to address archaeological and other heritage sites as economic assets BEST AND SUSTAINABLY EXPLOITED BY NOT DESTROYING THEM. The greatest threat to our shared past is destructive alternative economic uses-looting, agriculture, mining, commercial and residential development. These uses are not sustainable, and leave neither economic opportunity nor any history for future generations. Saving pasts builds better futures. 


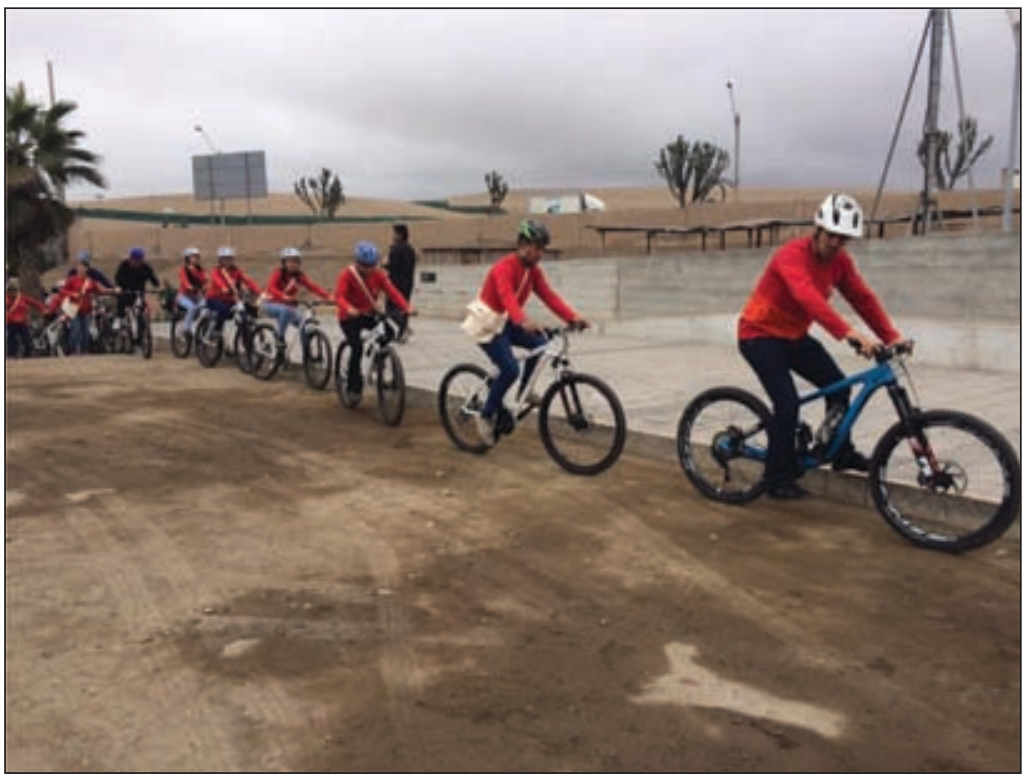

Figure 16. Bicitours, Pachacamac, Peru

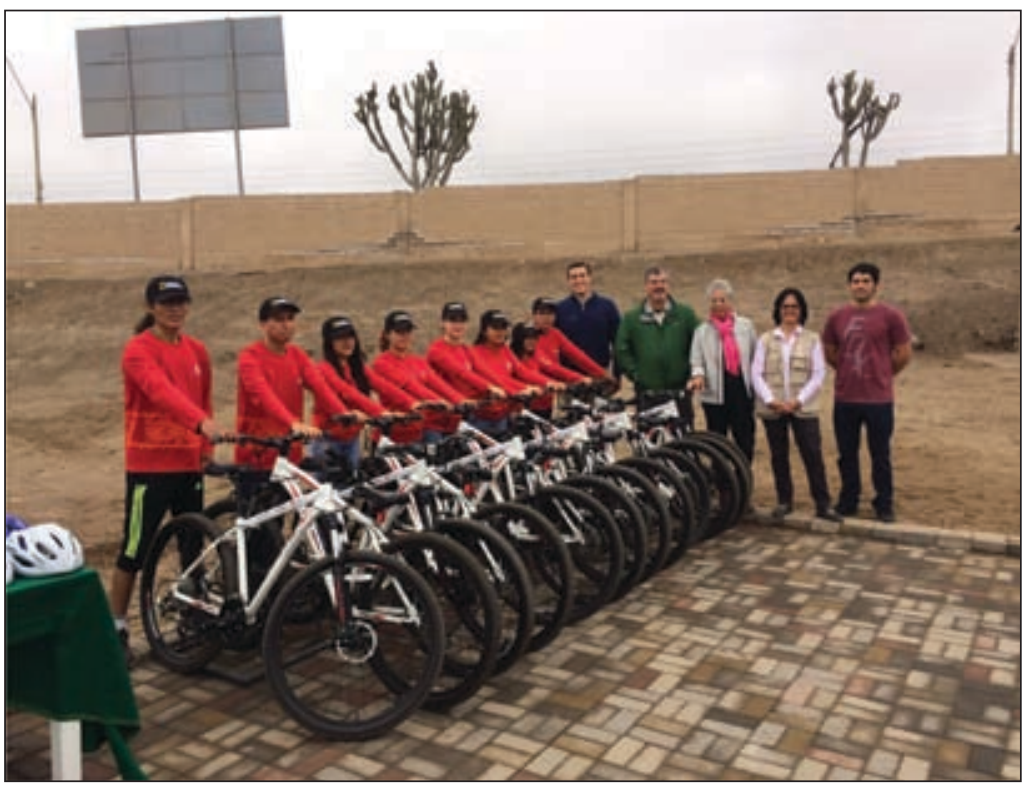

Figure 17. Bicitours, Pachacamac, Peru

6. Measure your results, adapt and modify your program accordingly. Everyone in our project has metrics regarding economic performance and site preservation, such as jobs created, revenues generated, looters' pits and site invasions.

We and our partner communities have learned, sometimes in a hard way, how to create thriving businesses that protect the past. I would like to share 


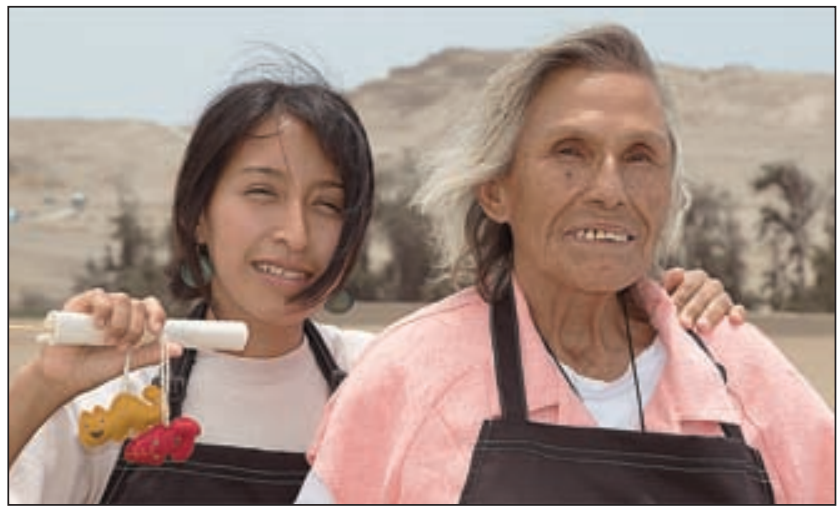

Figure 18. Oldest member of the SISAN cooperative (right)

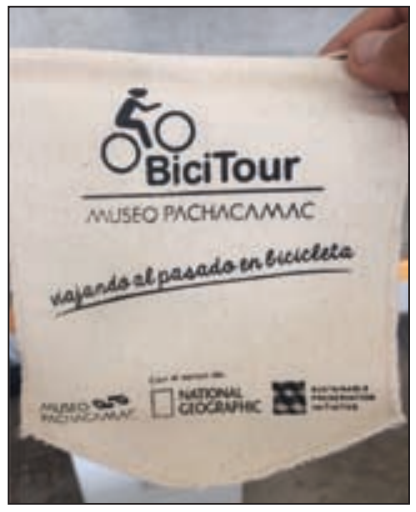

Figure 19. Bictours certificate

a few out of these many lessons with you, so that they can inform your work as they do to ours. And you do not need to work on an archaeological site to use them.

a. Utilize smaller-scale, community-based and derived solutions, and let them grow entrepreneurially and virally. Imposing top-down, overly large cookie cutter paradigms do not work. If you do not believe me, check out the work of Nobel Prize winner Elinor Ostrom - she agrees with us.

b. Teach people how to run businesses, not just pretty things. Tax, accounting, inventory, marketing, production - all need to be part of the mix. So does getting people into the formal economy. None of this is glamorous, but it is critical.

c. Understand and embrace the local social structure-do not try to impose a new one or some preset collection of ideas. Take cooperatives, associations, entrepreneurs and others for the most part as you find them. EXCEPT:

d. Even in the most macho areas, support women. Over $85 \%$ of the empowered entrepreneurs and workers we work with are women. Not just because they are smarter and better business people as many studies have shown, but because they are traditionally and wrongly excluded from the economic opportunity, and when they finally get a chance, they seize it, because, sadly, they may not get another one.

Empowering women also creates new remarkable role models and potential futures. We work in many macho areas. Time and again, when we enter a women community, whether they will speak with us at all, stare at their hand, speak softly or mumble and do not make eye contact. A year or two later we find them engaged, open, outgoing conversationalists who want to make videos and take pictures for their own and their business social media pages. 


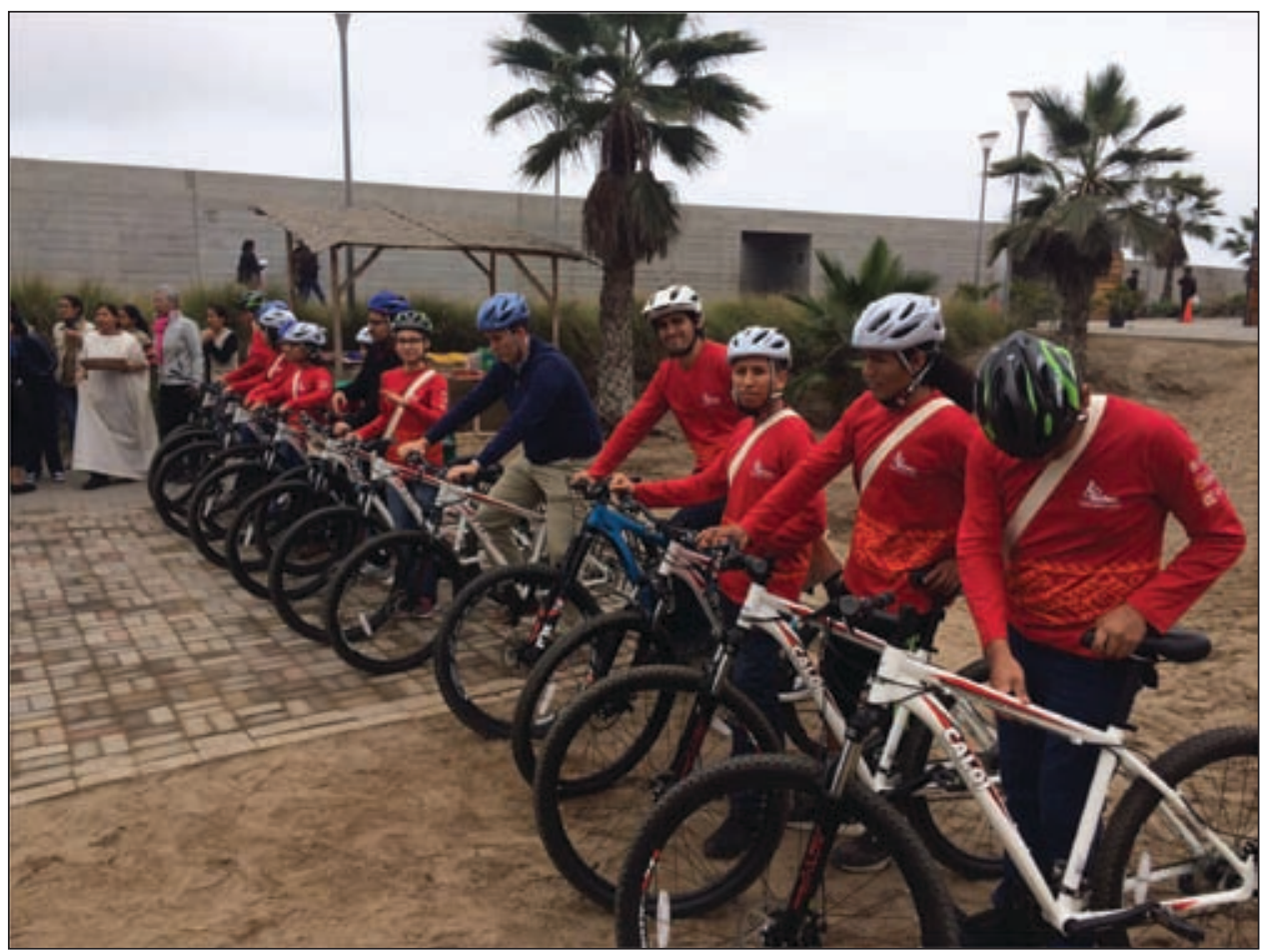

Figure 20. Bicitours, Pachacamac, Peru

Follow this path, IT WORKS! We have created empowered community members, jobs and income while saving numerous sites from destruction. You can get the details on our web page, but I will humble brag that a Reuter business/financial columnist called our job creation rate extraordinary! And empowering people to build futures has so many non-economic benefits: people eat better, go to the doctor more, stay in school longer, are less depressed, etc. When communities build futures, they do it holistically ... and they save pasts.

Best practices in archaeology have evolved to include, at least as a stated goal, economic, social and cultural benefits to the people and communities where they are located. While most archaeologists and heritage professionals pay lip service to this objective, many make little or no attempt to achieve it in practice. And even when community-based and focused projects are undertaken, few out of such benefits are actually realized, most frequently due to either poorly conceived or implemented plans, or both. By contrast, our methodology has created several long term sustainable businesses. Please, join us in building futures and saving pasts! 
Construirea viitorului, salvarea trecutului - dezvoltare durabilă și conservarea patrimoniului - calea SPI

\section{Rezumat}

Siturile arheologice dispar într-un ritm accelerat. În timp ce distrugerea de către ISIS și jefuirea acaparează toată presa, principalele cauze ale pierderii patrimoniului cultural sunt cele economice: dezvoltarea comercială și rezidențială, încălcările exploatării miniere, energetice, agricole, pentru a numi doar câteva. Dacă sursa problemei este una preponderent economică, de aceeași natură trebuie să fie și soluțiile. În abordarea noastră, aducem în discuție soluțiile economice cele mai eficiente, dar și cele sortite eșecului. Voi descrie cauzele funcționării proiectelor ce vizează abilitarea femeilor și dezvoltarea comunitară durabilă, de fapt, la scară mai mică, explicând de ce anume funcționează rareori proiectele la scară largă, detaşate de realitatea afacerilor. Programele de succes permit comunităților să-și construiască viitorul și să-și salveze trecutul.

Cuvinte cheie: dezvoltare durabilă, comunitate, împuternicirea femeilor, patrimoniu cultural, conservare.

Larry Coben, Sustainable Preservation Initiative (www.sustainablepreservation.org), e-mail: larrycoben@sustainablepreservation.org 